\title{
Apoptosis pattern elicited by oestradiol treatment of the seminiferous epithelium of the adult rat
}

\author{
J. Blanco-Rodríguez ${ }^{*}$ and C. Martínez-García \\ Department of Cell Biology, School of Medicine, Valladolid University, Ramón y Cajal, 7, 47005, \\ Valladolid, Spain
}

\begin{abstract}
It is widely assumed that oestrogen administration in the male mimics hypophysectomy by suppressing gonadotrophin secretion. Nevertheless, oestradiol treatment can increase germ-cell apoptosis mainly at stages IV-X of the spermatogenic cycle, rather than at stage VII when apoptotic germ-cell death is mainly triggered by gonadotrophin withdrawal caused by hypophysectomy. Since the roles of testicular oestrogens in spermatogenic regulation, if any, are unknown, we re-evaluated the germ-cell types that undergo apoptosis after oestradiol treatment. Adult male rats were injected daily with $50 \mu \mathrm{g}$ oestradiol, oestradiol plus testosterone propionate ( $25 \mathrm{mg}$ every 3 days) or oestradiol plus human menopausal gonadotrophin (equivalent to $25 \mathrm{iu} \mathrm{FSH}$ plus $25 \mathrm{iu} \mathrm{LH)} \mathrm{for} 15$ days. Apoptosis was assessed by in situ $3^{\prime}$-end labelling of internucleosomal DNA fragments in plastic semithin sections; the germ-cell types involved were identified by high-resolution light microscopy. The quantitative analysis of our results shows that the apoptosis pattern elicited by oestradiol treatment of the seminiferous epithelium differs from that reported to be caused by gonadotrophin or testosterone withdrawal, suggesting a possible role for oestradiol in the modulation of germ-cell death in the adult testis of the rat.
\end{abstract}

\section{Introduction}

The role played by testicular oestrogens in spermatogenic regulation, if any, remains unknown (Van der Molen et al., 1981; Nakhla et al, 1984; Le Magueresse and Jegou, 1988), although it is widely assumed that oestrogen administration in the male mimics the effect of hypophysectomy on the testis by suppressing gonadotrophin and testosterone secretion (Steinberger, 1971; Van der Molen et al., 1981). As a consequence, oestradiol treatment has been widely used to study spermatogenesis in the hormone-suppressed testis. However, male mice with disrupted genes encoding oestrogen receptors have low sperm counts (Smith et al., 1994) and decreased fertility (Lubahn et al., 1993). The high expression of oestradiol receptors in the testis has been demonstrated by Heikinheimo et al. (1995), suggesting that these receptors may have some important direct role in modulating the hormonal control of the spermatogenic process.

Spontaneous germ-cell death during spermatogenesis is an important event that has been estimated to result in the loss of up to $75 \%$ of potential mature sperm cells in the adult rat (Huckins, 1978). Dead cells can be found at all stages of the spermatogenic cycle (Blanco-Rodríguez and Martínez-García, 1996a). Earlier morphological studies showed that withdrawal of either gonadotrophins (Russell and Clermont, 1977; Russell et al., 1981; Ghosh et al., 1991) or testosterone (Sharpe et al., 1990; Kerr et al., 1993; O'Donnell et al., 1994) leads to a

${ }^{*}$ Correspondence.

Received 30 October 1996. marked increase in this type of cell death, mainly at stage VII. Since Tapanainen et al. (1993) proved that FSH and testosterone act as survival factors on the germ cells of the rat testis, it has been reported that enhanced apoptosis occurs at several stages of the cycle, after either gonadotrophin (Billig et al., 1995; Brinkworth et al., 1995; Marathe et al., 1995; Sinha-Hikim et al., 1995; Shetty et al., 1996) or testosterone (Henriksén et al., 1995) deprivation.

Previously, we analysed the temporal and stage-related changes in the kinetics of germ-cell apoptosis in the hormonesuppressed testis after oestradiol treatment and, in contrast to earlier published data (Russell et al., 1981), showed that stages IV-X are the most sensitive to germ-cell apoptosis (Blanco-Rodríguez and Martínez-García, 1996b). Since these results also differ from those reported in response to gonadotrophin or testosterone suppression (Billig et al., 1995; Brinkworth et al., 1995; Marathe et al., 1995; Sinha Hikim et al., 1995; Shetty et al., 1996), it seems reasonable to suggest that oestradiol plays a role in the modulation of apoptosis regulation.

The major objectives of this study were to determine the stages of spermatogenesis at which apoptosis is elicited on germ cells by oestradiol treatment and to determine whether gonadotrophins or testosterone are able to bring about the full recovery of the oestradiol-suppressed testis, as they can in hypophysectomized animals. These goals were achieved by assessing apoptosis by in situ $3^{\prime}$-end labelling of internucleosomal DNA fragmentation in plastic semithin sections. Dying germ-cell types were identified and quantified by high-resolution light microscopy in the seminiferous epithelium 
from rats treated with oestradiol, oestradiol plus testosterone or oestradiol plus human menopausal gonadotrophin (hMG).

\section{Materials and Methods}

\section{Animals and hormone treatment}

Adult male Wistar rats $(n=20)$ weighing $250-300 \mathrm{~g}$ were housed under conventional, controlled standard conditions. The animals were divided into four groups of five. Animals in each group were treated as follows: group I received $50 \mu \mathrm{g}$ oestradiol 3-benzoate (Sigma Chemical Co., St Louis, MO), suspended in $0.25 \mathrm{ml}$ olive oil (vehicle), i.m. daily for 15 days; group 2 (testosterone-supplemented, oestradiol-treated rats) were additionally injected i.m. with $25 \mathrm{mg}$ testosterone propionate (4-androgen-17 $\beta$-ol-3-one 17 propionate, Sigma Chemical Co.) every 3 days; group 3 (gonadotrophinsupplemented, oestradiol-treated animals) received, in addition to oestradiol, one daily i.m. injection of human menopausal gonadotrophin (hMG, Farma-Lepori, SA, Barcelona), equivalent to 25 iu FSH plus 25 iu LH; the control group received the vehicle alone. This kind of oestradiol treatment has previously been shown to reduce significantly the concentration of testosterone as well as of gonadotrophins in the plasma and testes (Jong et al., 1975) and to cause large numbers of germ cells to die, while still allowing the seminiferous tubule stages to be identified (Blanco-Rodríguez and Martínez-García, 1996c). The dose of testosterone was chosen based on the findings of previous studies (Sharpe et al., 1987, 1988) so that the testosterone concentration would maintain spermatogenesis quantitatively.

\section{Tissue preparation}

Twenty-four hours after the last treatment, animals of all groups were injected with heparin (500 iu per $100 \mathrm{~g}$ body mass i.p.), $45 \mathrm{~min}$ before pentobarbital anaesthesia, to facilitate testicular perfusion. Blood samples were collected from each animal by cardiac puncture inmediately before death and plasma was separated and stored at $-20^{\circ} \mathrm{C}$ for subsequent hormone assays.

The thoracic aorta was cannulated and the vasculature flushed with buffered sodium chloride before perfusion fixation with $0.5 \% \quad(\mathrm{v} / \mathrm{v})$ glutaraldehyde and $1 \%(\mathrm{w} / \mathrm{v})$ paraformaldehyde in phosphate buffer $\left(0.05 \mathrm{~mol}^{-1}, \mathrm{pH} 7.4\right)$. The fixed testes were then removed and sliced transversally into approximately $1 \mathrm{~mm}$ thick slabs. Slabs were then cut into 18-20 small blocks $\left(1 \mathrm{~mm}^{3}\right)$ and placed in the same fixative (blocks from the left testes) or in $2 \%(\mathrm{v} / \mathrm{v})$ glutaraldehyde and $2 \%(w / v)$ paraformaldehyde (blocks from the right testes) for an additional $20-24 \mathrm{~h}$. All the blocks were washed overnight in phosphate buffer $\left(0.1 \mathrm{~mol}^{-1}, \mathrm{pH} 7.4\right)$ and only those from the right testes were post-fixed with $2 \%(\mathrm{w} / \mathrm{v})$ osmium tetroxide in the same buffer for $2 \mathrm{~h}$. The tissues were then dehydrated in ascending concentrations of acetone, infiltrated with propylene oxide and embedded in Agar-100 (Agar Scientific Ltd, Stansted; blocks from the left testes) or Spurr (Polysciences Inc., Northampton, UK; blocks from the right testes) plastic (that is, epon or araldite, respectively). Orthogonal sections ( $1 \mu \mathrm{m}$ thick) across the seminiferous tubules were stained with a solution containing $1 \%(\mathrm{w} / \mathrm{v})$ toluidine blue and $1 \%(\mathrm{w} / \mathrm{v})$ sodium borate and examined under the light microscope.

\section{Hormone assays}

The concentrations of LH and FSH in the plasma were measured by a double radioimmunoassay method, using reagents provided by the National Pituitary and Hormone Distribution Program (NIDDK, Bethesda, MD). All samples were measured in duplicate. The minimal detection limits in the assay were $50 \mathrm{pg} \mathrm{ml}^{-1}$ for $\mathrm{LH}$ and $200 \mathrm{pg} \mathrm{ml}^{-1}$ for FSH. The intra-assay and interassay coefficients of variation were $8 \%$ and $9 \%$, respectively, for $\mathrm{LH}$ and $7 \%$ and $10 \%$, respectively, for FSH.

\section{Basic parameter measurements}

Spurr plastic semithin sections ( $1 \mu \mathrm{m}$ thick) were used. Ten round tubules at a minimal distance of $500 \mu \mathrm{m}$ were selected randomly from samples from each animal of the control $(n=5)$, the oestradiol-treated $(n=5)$ and the oestradiol-treated, hormone-supplemented $(n=5)$ groups, taking care that all the classic stages of the spermatogenic cycle were equally represented in every group.

The tubule diameters and the seminiferous epithelium areas were determined below the $\times 10$ objective, using an image analyser (JAVA, Jandel Scientific Co., Cortematera, CA) linked to a Zeiss photomicroscope. The diameters were measured across the minor axis of the tubule profiles. The seminiferous epithelium areas were calculated by subtracting the tubule lumen area from the whole tubule section area. A Jandel Video Analysis Software morphometric program was used for processing the measurements.

The number of Sertoli cell nuclei per tubular cross-section was determined by counting only those nuclei that occurred mostly within the tissue section. Counts were made at $\times 630$ magnification by two different observers.

\section{Enumeration of degenerating and viable germ cells and staging criteria}

Orthogonal Spurr plastic sections ( $1 \mu \mathrm{m}$ thick) of seminiferous tubules were examined at $\times 630$, using a $\times 63$ (1.4 N.A.) planapochromatic oil immersion objective. According to the type of spermatogonia, tubule staging followed the simplified classification proposed by Huckins (1978). Correspondence between this classification and the staging criteria proposed by Hess (1990) for plastic semithin sections is as follows: stage 1 = stages VII-early IX and is characterized by the presence of AI spermatogonia, preleptotene spermatocytes and step 7-9 spermatids; stage $2=$ mid-IX-early $X I I$ and contains A2 spermatogonia and leptotene spermatocytes; stage $3=$ mid-stage XII-XIV and contains A3 spermatogonia and primary zygotene to secondary spermatocytes; stage $4=$ stage I; stage $5=$ stages II-IV and is characterized by the presence of intermediate spermatogonia; stage $6=$ stages $V-V I$ and is diagnosed by the observation of $B$ spermatogonia. Degenerating germ cells were identified using previously 
Table 1. The concentrations of LH and FSH in control and hormone-treated adult male rats

\begin{tabular}{|c|c|c|c|c|}
\hline $\begin{array}{l}\text { Hormone } \\
\text { (ng } \mathrm{ml}^{-1} \text { ) }\end{array}$ & $\begin{array}{l}\text { Control } \\
\text { rats }\end{array}$ & $\begin{array}{l}\text { Rats } \\
\text { treated with } \\
\text { oestradiol }\end{array}$ & $\begin{array}{c}\text { Rats treated with } \\
\text { oestradiol and } \\
\text { testosterone }\end{array}$ & $\begin{array}{l}\text { Rats treated with } \\
\text { oestradiol and } \\
\text { human menopausa } \\
\text { gonadotrophin }\end{array}$ \\
\hline $\mathrm{LH}$ & $0.35 \pm 0.05$ & $0.09 \pm 0.04^{\mathrm{a}}$ & $0.20 \pm 0.07^{\mathrm{a}, \mathrm{b}}$ & $0.17 \pm 0.08^{a, b}$ \\
\hline FSH & $11.80 \pm 0.90$ & $1.35 \pm 0.3 \mathrm{I}^{\mathrm{a}}$ & $7.58 \pm 1.03^{\mathrm{a} . \mathrm{b}}$ & $20.43 \pm 1.92^{a, b}$ \\
\hline
\end{tabular}

Values are means \pm SEM.

Means with different superscripts are significantly different: ${ }^{a} P<0.05$ compared with control animals; ${ }^{b} P<0.05$ compared with animals treated with oestradiol alone.

reported criteria (Russell and Clermont, 1977; BlancoRodríguez and Martínez-García, 1996a,b) and scored. Dying elongated spermatids were not scored because their condensed nuclei made it difficult to distinguish them with accuracy. Counts of degenerating germ cells were expressed as a ratio to the number of Sertoli cell nuclei. For each rat of the control $(n=5)$ and oestradiol-treated $(n=5)$ groups, ten nonconsecutive sections at every stage were randomly selected, taking care that each of the 14 classic stages of the seminiferous epithelium were equally represented. A total of 50 tubules representing each stage were studied per group of animals.

Spermatogenesis in each group of animals was evaluated further: the stages of the seminiferous epithelial cycle were identified as described by Hess (1990) and the number of viable germ cells per tubular cross-section was determined in staged tubules, using the image analyser as indicated above. B spermatogonia were counted in stage $\mathrm{Vl}$, preleptotene spermatocytes and step 7 spermatids in stage VII, leptotene spermatocytes in stage IX, early pachytene spermatocytes and step $I$ spermatids in stage I, and zygotene and late pachytene spermatocytes in stage XII. For each rat, five nonconsecutive sections at every stage were used. A total of 25 tubules representing each stage were studied per group of animals. The number of viable cells was expressed as a ratio per Sertoli cell nucleus and as the number per cross-section, corrected according to the formula of Abercrombie (1946).

\section{Assessment of apoptosis}

The occurrence of germ-cell apoptosis was further characterized by direct immunoperoxidase detection of digoxigenin-labelled genomic DNA in semithin sections ( $1 \mu \mathrm{m}$ thick) fixed in $0.5 \%(\mathrm{v} / \mathrm{v})$ glutaraldehyde plus $1 \%$ $(\mathrm{w} / \mathrm{v})$ paraformaldehyde and embedded in agar using the Oncor ApopTag nonradioactive detection kit (Oncor Inc., Gaithersburg). In brief, agar plastic sections were deplastified, hydrated and treated with $10 \mu \mathrm{g}$ proteinase $\mathrm{K} \mathrm{ml}^{-1}$ (Boehringer Mannheim, Mannheim) for $15 \mathrm{~min}$ at room temperature. DNA $3^{\prime}$-end labelling with nonradioactive digoxigenin-ddUTP (dig-ddUTP) was performed by incubation at $37^{\circ} \mathrm{C}$ in a humidified chamber for $1 \mathrm{~h}$. Reaction mixture containing terminal transferase reaction buffer, dig-ddUTP and terminal deoxynucleotidyl transferase (TdT) was used following the supplier's guidelines, with slight modifications for plastic sections. DNA strand breaks were revealed after the incubation with antidigoxigenin antibody conjugated to peroxidase at room temperature for $30 \mathrm{~min}$ and the subsequent detection of the enzyme activity using 3,3'-diaminobenzidine (DAB) as substrate, as recommended. Finally, slides were counterstained in toluidine blue. For each animal of the control group and rats treated with oestradiol only, at least five tubules at each of the stages 1-6 (Huckins, 1978) of the seminiferous epithelial cycle were examined at $\times 630$ magnification using an oil immersion objective for in situ localization of apoptotic cells.

Negative controls were processed in an identical manner except that the TdT enzyme was substituted by the same volume of distilled water. Mildly $\left(43^{\circ} \mathrm{C}\right.$ for $\left.15 \mathrm{~min}\right)$ heattreated testes were used as positive controls for every assay.

Because Oncor recommends $10 \%(\mathrm{v} / \mathrm{v})$ formalin-fixed, paraffin-embedded sections for apoptosis detection with the ApopTag kit, we also tested the validity of using $0.5 \%(\mathrm{v} / \mathrm{v})$ glutaraldehyde plus $1 \%(\mathrm{w} / \mathrm{v})$ paraformaldehyde fixation and agar embedding for cellular localization of apoptosis in the testis. Testes for additional groups of controls and rats treated with oestradiol were fixed with $10 \%(\mathrm{v} / \mathrm{v})$ formalin and processed for routine paraffin embedding. No changes in ApopTag staining were apparent between tissues fixed in formalin or in glutaraldehyde plus paraformaldehyde.

\section{Statistical analysis}

Data were analysed for statistical significance by calculating the means, SEMS and ANOVA. $P$ values were determined by Scheffe's test for basic parameters and the data for viable germ-cell populations and by the chi-squared test with Yate's corrections for data for dying cells.

\section{Results}

\section{Hormone concentrations}

Hormone data from control and hormone-treated animals are summarized (Table 1). In the oestradiol-treated animals (group 1), the plasma FSH as well as $\mathrm{LH}$ concentrations were consistently suppressed by greater than $88 \%$ and $75 \%$, respectively, compared with corresponding concentrations in vehicletreated animals. In the testosterone-supplemented animals (group 2), the serum concentrations of both hormones were raised with respect to rats that received oestradiol alone, 

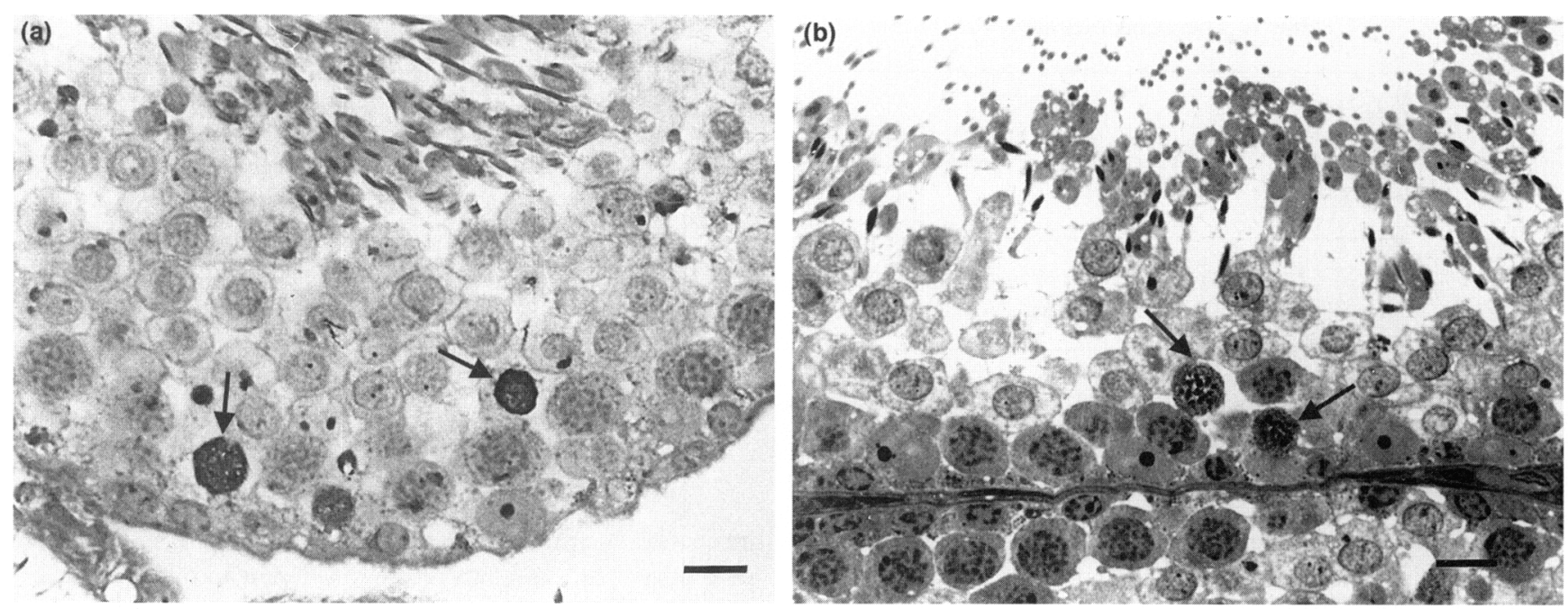

Fig. 1. (a) In situ detection of apoptotic cells in an agar-embedded semithin section of a seminiferous tubule at stage VII from an adult male rat treated with oestradiol for 15 days. The section was fixed in $0.5 \%(\mathrm{v} / \mathrm{v})$ glutaraldehyde plus $1 \%(\mathrm{w} / \mathrm{v})$ paraformaldehyde. Arrows point to pachytene spermatocytes undergoing apoptosis. (b) Toluidine blue staining of apoptotic cells in a stage VII seminiferous tubule. The figure shows a Spurr semithin section from the contralateral testis of the same animal shown in (a), postfixed with $2 \%(\mathrm{v} / \mathrm{v}$ ) glutaraldehyde plus $2 \%$ (w/v) paraformaldehyde. Arrows point to dying pachytene spermatocytes. Scale bars represent $10 \mu \mathrm{m}$.

although they remained decreased (FSH by $36 \%$, LH by $43 \%$ ) compared with control values. In the gonadotrophinsupplemented rats (group 3), the plasma FSH concentration was 1.73 times greater while the plasma LH concentration was lower (by $51 \%$ ) than the control values.

\section{In situ analysis of DNA fragmentation}

The specific cell types that underwent apoptosis after oestradiol treatment were assessed by direct immunoperoxidase detection of digoxigenin $3^{\prime}$ end-labelled DNA fragments in semithin ( $1 \mu \mathrm{m}$ thick) sections of agar-embedded seminiferous tubules. In most cases, high-resolution light microscopy allowed the accurate identification of apoptotic germ-cell types that incorporated digoxigenin-ddUTP in the immunostained agar sections. The distribution of these labelled cells showed an overall coincidence with the distribution of degenerating cells appearing in toluidine-blue-stained, Spurr plastic semithin sections (Fig. 1), in both control and experimental groups. Nevertheless, the number of dying cells in all of the oestradiol-treated animals appeared to be more than that in control animals. Immunostained cells did not appear in the interstitial space but all the germ-cell types could be found labelled and scattered among healthy cells in the seminiferous tubules from oestradiol-treated animals.

\section{Basic parameters}

In oestradiol-treated rats (group 1), the seminiferous tubule diameter and seminiferous epithelium areas of the seminiferous tubules decreased to $63 \%(P<0.001)$ and $38 \%(P<0.001)$ of the control values, respectively. Both parameters were significantly $(P<0.001)$ restored after testosterone (group 2 ) or gonadotrophin (group 3) supplementation with respect to animals treated with oestradiol alone but they remained significantly $(P<0.001)$ lower than values for control animals. In contrast, statistically significant differences were not found between groups 2 and 3 (Fig. 2a,b).

A statistically significant $(P>0.001)$ decline in the number of Sertoli cell nuclei per cross-section of seminiferous tubule was also demonstrated in rats treated with oestradiol alone, which averaged 16 nuclei, compared with control rats, which averaged 23.6 nuclei (Fig. 2c). The number of Sertoli cells in the epithelium significantly recovered after either testosterone $(P<0.001)$ or gonadotrophin $(P<0.05)$ treatment, averaging 20 and 18 nuclei, respectively, but remained significantly $(P<0.001)$ decreased with respect to the control figures. A statistically significant difference $(P<0.05)$ was also found between both hormone replacement treatments (Fig. 2c).

\section{Identification of the most vulnerable stages and germ-cell types to oestradiol treatment}

Degenerating cells could easily be recognized in Spurr plastic semithin sections by their prominent basophilia and the shrinkage of both the cytoplasm and the nucleus, which often left an empty space around the cell. Because they were usually scattered among healthy cells and kept, in most cases, their main morphological features and correct positions (Fig. Ib), they were readily identifiable until late in these toluidine-bluestained semithin sections, even when the process of degeneration was very advanced. Residual bodies of spermatozoa at stage IX, which have similar staining characteristics, are also easily identified and the possibility of mistaking them for degenerating celis is very low.

To identify the specific spermatogenic stages and the germ-cell types that were the most vulnerable to oestradiol 
(a)

(b)

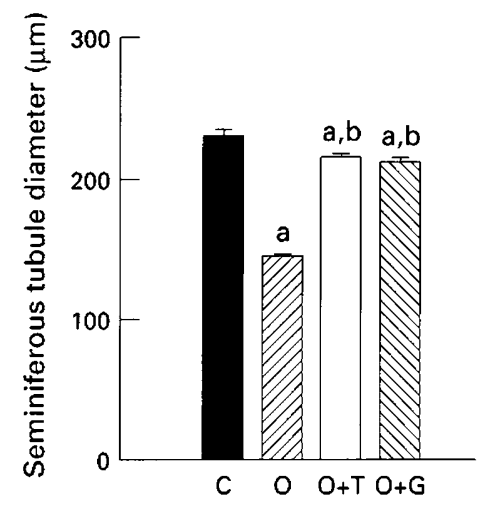

Hormone treatment

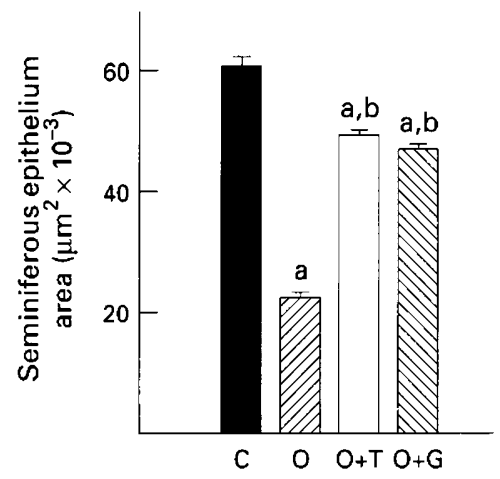

Hormone treatment \{c\}

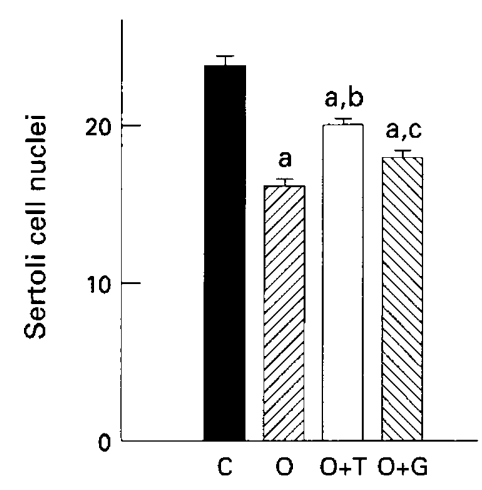

Hormone treatment

Fig. 2. Changes in the basic parameters of seminiferous tubules of adult male rats ((a) seminiferous tubule diameter, (b) seminiferous epithelium areas and (c) Sertoli cell number) in response to oestradiol treatment (『), and to testosterone ( $\square$ ) and gonadotrophin $(\mathbb{Q})$ replacement, with respect to control $(\boldsymbol{\square})$ animals. Values are means \pm SEM $(n=5$ rats). Means with different superscripts differ significantly: ${ }^{a} P<0.001$ compared with control animals; ${ }^{b} P<0.001,{ }^{c} P<0.05$ compared with rats treated with oestradiol alone.

treatment, we further quantified dying cells at each stage and at each selected maturing step in the testes from oestradioltreated rats and from rats supplemented with testosterone or gonadotrophin.

Group 1. A significantly increased number of dying germ cells appeared in response to oestradiol treatment at nearly all the stages of the spermatogenic cycle in the seminiferous epithelium (Fig. 3). The greatest increase was found at stage 6 , corresponding to V-VI ( $>100$-fold increase, $P<0.001$ ), where degenerating cells were very difficult to find in control animals, although a larger number of dying cells was found at stage 1 , corresponding to VII-IX (60-fold increase, $P<0.001$ ). Surprisingly, the smallest increase in dying cells appeared at stage 3 , corresponding to XII-XIV (1.4-fold increase), which was not statistically significant (Fig. 3).

The degree of degeneration was also increased in nearly all the germ-cell types, with the exception of A2 spermatogonia, primary metaphase spermatocytes and B spermatogonia (Fig. 4). Nevertheless, cell death became statistically significant $(P<0.001)$ only in cells after passing the testis barrier. The germ-cell types affected mostly were elongating spermatids, followed by round spermatids, whereas pachytene spermatocytes and resting secondary spermatocytes were only moderately sensitive to oestradiol treatment. A very striking finding was that the number of dying primary metaphase spermatocytes was significantly lower than in control animals (1:3.86 decrease, $P<0.001$ ). The number of dying A2 spermatogonia was also lower than that in control rats, although this decrease was not statistically significant.

Group 2. This group of animals was administered $25 \mathrm{mg}$ testosterone every 3 days along with the oestradiol treatment to determine whether the effect of oestradiol treatment can be fully reversed by simultaneous administration of testosterone. The recovery of the seminiferous epithelium was visibly demonstrated and statistical analysis of the quantitative results revealed that germ-cell degeneration declined significantly $(P<0.001)$ at all stages with respect to the rats treated with oestradiol alone (Fig. 3). Nevertheless, no significant increases in the number of dead cells were found at stages 1 (VII-IX) and 4-6 (I-VI) compared with control values (Fig. 3). A striking finding was the significant decrease $(P<0.001)$ in the number of dying cells at stage 3 (mid-XII-XIV) compared with that in rats treated with oestradiol alone and also compared with the control group (Fig. 3), in spite of the significant increase (13-fold, $P<0.001$ ) in the number of dying secondary spermatocytes in rats treated with testosterone compared with that in control animals (Fig. 4). It is also interesting to note that a non-significant decrease in cell degeneration also occurred at stage 2 (IX-early XII) with respect to the control group (Fig. 3). The analysis of germ-cell types undergoing degeneration revealed that these decreases were due mostly to the striking decrease observed in the number of degenerating primary metaphase spermatocytes compared with control values (1:22.7, $P<0.001$ ), which was found to be an even greater decrease than that found in rats treated with oestradiol alone $(1: 4, P<0.001)$. The statistically significant $(P<0.05)$ diminution of dying zygotene spermatocytes, which were not observed at all in this group of animals, and the non-significant decrease in dying A2 spermatogonia (1:1.7) also lowered the number of dying germ cells appearing at these stages. Nevertheless, no significant increases in the number of degenerating germ cells were found in nearly all the germ-cell types, compared with control values (Fig. 4).

Group 3. In a similar way, epithelial cell degeneration was analysed in oestradiol-treated animals supplemented daily with hMG (25 iu FSH plus $25 \mathrm{iu} \mathrm{LH}$ ). The restoration of spermatogenesis was demonstrated in this group (Fig. 3) and the decrease in germ-cell degeneration after gonadotrophin supplementation was statistically significant $(P<0.001)$ at stages $I(V I I-I X)$ and $4-6(I-V I)$ with respect to rats treated with oestradiol alone. These stages correspond to all the spermatogenic stages in which germ-cell degeneration was 


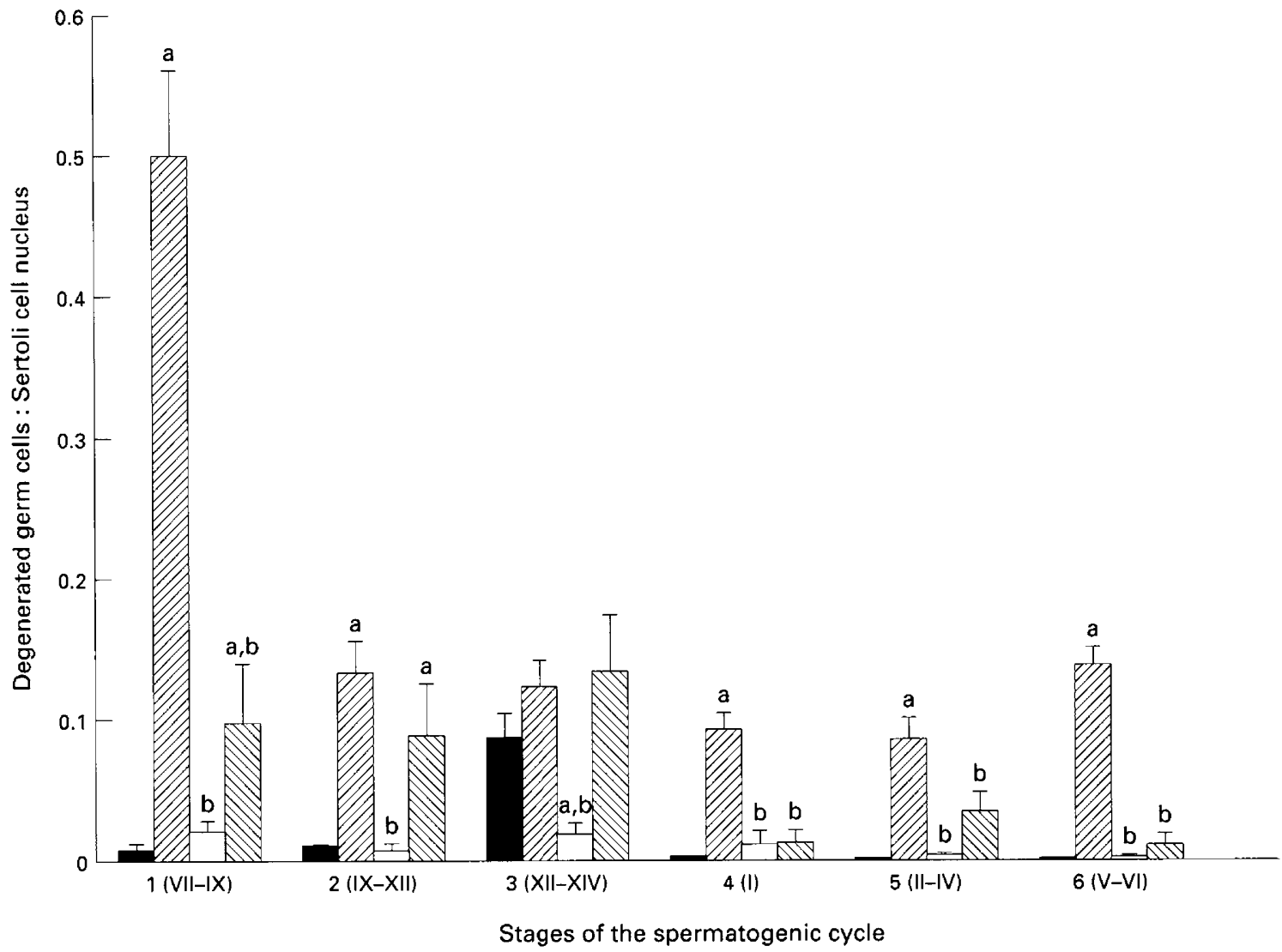

Fig. 3. Quantification of stage-specific germ-cell degeneration in control and experimental adult male rats ( $\boldsymbol{\square})$ control: ( $(\Delta)$ treated with oestradiol alone, $(\square)$ oestradiol and testosterone, or $(\mathbb{Q})$ oestradiol and human menopausal gonadotrophin, hMG). Degenerating germ cells were counted at all the stages of the spermatogenic cycle and expressed as a ratio of these cells to Sertoli cell nucleus; staging was established according to Huckins (1978) and was based on the spermatogonia type $(1=\mathrm{A} 1,2=\mathrm{A} 2,3=\mathrm{A} 3,4=\mathrm{A} 4,5=$ intermediate, $6=\mathrm{B})$. Values are means $\pm \mathrm{SEM}(n=5$ rats $)$. Means with different superscripts differ significantly: ${ }^{a} P<0.01$ compared with control animals; ${ }^{b} P<0.01$ compared with rats treated with oestradiol alone.

enhanced by the oestradiol treatment, with the exception of stage 2 (corresponding to IX-XII). Nevertheless, the number of dying cells in the testes from this group of rats was greater than in control animals at all stages, ranging from fivefold to 24-fold increases, although these increases with respect to control animals were found to be significant $(P<0.01)$ only at stages 1 and 2, corresponding to VII-XII (Fig. 3), in which the most affected cells were preleptotene and leptotene spermatocytes (Fig. 4). This statistically significant $(P<0.01)$ larger number of dying preleptotene and leptotene spermatocytes, compared with both control rats and rats treated with oestradiol alone, as well as of zygotene spermatocytes $(P<0.05)$ compared with control animals, was a striking finding. It is also interesting that intermediate and B spermatogonia degenerated only in this group of animals, although statistical significance was not found by analysis of variance. In addition, in contrast to the situation in groups 1 and 2, the statistical analysis of the number of dying primary metaphase spermatocytes failed to reveal any significant difference with respect to control rats, although it was significantly $(P<0.001)$ increased compared with that in rats treated with oestradiol alone or with testosterone supplementation (Fig. 4).

\section{Viable germ-cell populations}

Quantification of spermatogenesis by germ-cell counts at specific maturing steps in control and treated animals was expressed as a ratio per Sertoli cell nucleus and as the number of cells per tubular cross-section, corrected according to Abercrombie's formula (Table 2). As expected, oestradiol treatment caused a strong decrease in the number of step 1 and step 7 spermatids per Sertoli cell nucleus $(P<0.001)$ compared with control rats, whereas hormone replacement resulted in a significant increase in these cell counts $(P<0.001)$ compared with rats treated with oestradiol alone. Nevertheless, it is interesting to note that increases in the number of $B$ spermatogonia, and preleptotene, leptotene and zygotene spermatocytes appeared in testes from all the experimental animals, with respect to control values, although only some of these increases were statistically significant (Table 2).

Similar to the values of cell counts expressed per Sertoli cell nucleus, counts of the number of cells per tubule cross-section in the testes from rats that received oestradiol alone (corrected to Abercrombie's formula) showed a statistically significant reduction $(P<0.01)$ compared with control animals in 


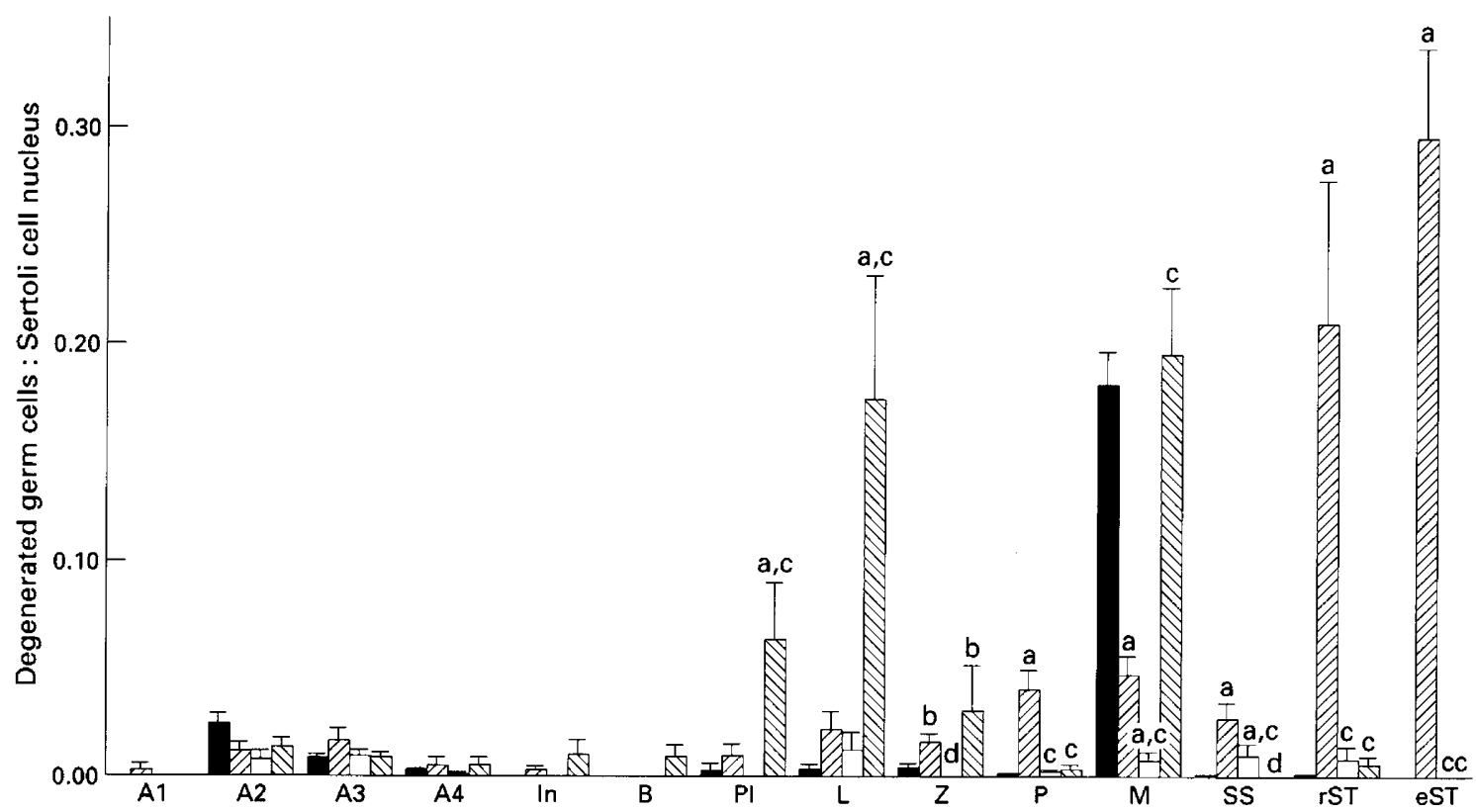

Fig. 4. Quantification of degeneration in spermatogonia (A1, A2, A.3, A4, intermediate (In), B), preleptotene (Pl), leptotene $(\mathrm{L})$, zygotene $(\mathrm{Z})$, pachytene $(\mathrm{P})$ and primary metaphase $(\mathrm{M})$ spermatocytes, secondary spermatocytes (SS) and round (rST) and elongating (eST) spermatids, in seminiferous tubules from control and groups of adult male rats ((口) control: () treated with oestradiol alone, $(\square)$ oestradiol and testosterone, or $(\mathbb{\nabla})$ oestradiol and human menopausal gonadotrophin (hMG)). Values are means $\pm \operatorname{SEM}\left(n=5\right.$ rats). Means with different superscripts differ significantly: ${ }^{\mathrm{a}} P<0.01,{ }^{b} P<0.05$ compared with control animals; ${ }^{c} P<0.01,{ }^{\mathrm{d}} P<0.05$ compared with rats treated with oestradiol alone.

Table 2. Quantification of spermatogenesis in seminiferous tubules from control and hormone-treated adult male rats

Germ-cell type

\section{B}

Pl

$$
\text { L }
$$

$$
\text { Z }
$$

$$
\text { IP }
$$

\section{$12 \mathrm{P}$}

IST

7ST
Cell counts per Sertoli cell nucleus
Cell counts per tubular cross-section (corrected to Abercrombie's formula)

\footnotetext{
Values are means \pm seM.

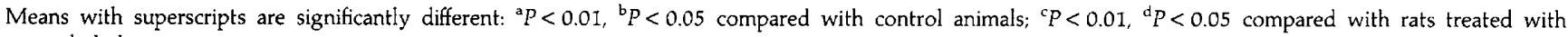
oestradiol alone.

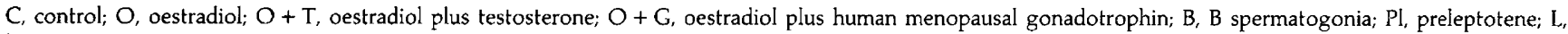
leptotene; Z, zygotene; IP, stage I pachytene spermatocytes; 12P, stage XII pachytene spermatocytes; IST, step 1 spermatids; $7 S T$; step 7 spermatids.
}

pachytene spermatocytes and spermatids, while the number of B spermatogonia $(P<0.05)$, and preleptotene $(P<0.01)$ and zygotene $(P<0.05)$ spermatocytes of these animals were significantly increased compared with control values. In contrast, spermatocyte and spermatid counts per tubular crosssection in testes from animals that received hormone replacement were significantly recovered $(P<0.001)$ compared with rats treated with oestradiol alone. Similar to counts per Sertoli cell nucleus, the numbers of B spermatogonia and early spermatocytes were slightly greater than in control rats. In general, these increases were greater in animals treated with oestradiol alone and were significantly diminished ( $P$ ranging from $<0.01$ to $<0.05$ ) compared with rats treated with oestradiol alone after testosterone supplementation, and to a lesser degree, after gonadotrophin replacement (Table 2).

\section{Discussion}

Although the role played by testicular oestrogens in spermatogenic regulation remains unknown (Van der Molen 
et al., 1981; Nakhla et al., 1984; Le Magueresse and Jegou, 1988), it is widely accepted that oestradiol treatment mimics the effect of hypophysectomy in the testis, due to gonadotrophin and testosterone suppression (Steinberger, 1971; Russell et al., 1981; Van der Molen et al., 1981; McLachlan et al., 1994). In our study, oestradiol treatment for 15 days resulted in more than a $75 \%$ and an $85 \%$ suppression of $\mathrm{LH}$ and FSH concentrations, respectively; that is, its effects on germ-cell degeneration should be equivalent to other gonadotrophinsuppressing treatments. However, in contrast to previous observations (Russell et al., 1981), the present data provide evidence that the apoptotic germ-cell pattern shown after oestradiol treatment differs from those reported to be caused by hypophysectomy (Clermont and Morgentaler, 1955; Russell and Clermont, 1977; Russell et al., 1981), GnRH antagonist treatment (Billig et al., 1995; Brinkworth et al., 1995; Sinha Hikim et al., 1995) or testosterone deprivation (Sharpe et al., 1988; Kerr et al., 1993; Henriksén et al., 1995). Thus, in our study, stage 1 (following Huckins' criteria, and corresponding to VII-early IX) has been revealed as one of the most sensitive stages to oestradiol treatment, although the number of dying cells is significantly increased at nearly all the stages, with the exception of stage 3 (corresponding to stages XII-XIV). With respect to germ-cell types that respond to hormone suppression, Billig et al. (1995), Marathe et al. (1995) and Brinkworth et al. (1995), using a GnRH antagonist, LH immunoneutralization or testosterone deprivation, reported that the cells most affected were pachytene spermatocytes. This is in direct contrast to the results obtained in the present study after oestradiol treatment, in which the most affected cells were elongating (step 9-10) spermatids, followed by round spermatids, whereas pachytene spermatocytes appeared less sensitive.

In situ end-labelling of apoptotic cells in agar-embedded semithin sections is an accurate technique to diagnose germ-cell types undergoing apoptosis. However, as it is very likely that the label incorporates into cells only in certain phases of cell death (Henriksén et al., 1995) and the intimate association between apoptosis and germ-cell degeneration has been shown (Sinha Hikim et al., 1995), the identification of degenerating cells by high-resolution light microscopy provides a very useful method for precise quantification of the dying germ-cell types. In contrast, electrophoresis of DNA in agarose gels to give characteristic DNA laddering or in situ end-labelling to detect the DNA strand breaks have serious limitations when analysing stage-specific apoptosis in the seminiferous epithelium because (1) the previous staging of microdissected seminiferous tubule segments must be performed and the number of dying cells can represent only a small percentage of the total tissue mass, and because (2) paraffin embedding does not allow enough resolution to identify readily all the germ-cell types involved. Squash preparations of selected stages of the cycle combined with in situ end-labelling of the DNA fragments is an effective method to quantify estimates but the large number of cells makes it difficult to identify the precise germ-cell type involved (Henriksén et al., 1995). In addition, it should be taken into account that cells dying by apoptosis do so singly and are then rapidly phagocytosed, so that they are not always apparent in histological sections; however, if, as demonstrated in studies in vitro, cells enter the apoptotic pathway continuously after the eliciting event, increasing treatment periods will cause increasing numbers of dying cells to accumulate and they will become easier to observe. If this is the case, very short-term treatments are unsuitable for establishing all the sensitive cell types and their degree of vulnerability.

Taking the above into account, it is possible that the distinct approaches used by the different authors may, at least partially, account for some of the apparent discrepancies. Nevertheless, some of our results are difficult to explain on the basis of technical differences. For example, although it is well established that the dose of testosterone administrated is able to restore spermatogenesis completely in hormone-deprived animals (Sharpe et al., 1987; Awoniyi et al., 1989; Kerr et al., 1993; McLachlan et al., 1994), in our experiments neither testosterone nor gonadotrophin supplementation were able to maintain any of the basic parameters measured at control values, and dying cells were observed more frequently in the testes from both hormone-supplemented groups of rats compared with control animals. Another striking finding was the highly significant reduction in the number of dying primary metaphase spermatocytes and, to a lesser degree, in dying A2 spermatogonia, after oestradiol treatment and after the combined administration of oestradiol with testosterone, compared with that in control and gonadotrophin-supplemented animals. Since these germ-cell types die frequently in intact animals and such spontaneous degeneration increases after hypophysectomy (Clermont and Morgentaler, 1955; Russell and Clermont, 1977), GnRH antagonist administration (Billig et al., 1995) and testosterone withdrawal (Dym and Madhwa Raj, 1977; Sharpe et al., 1990; Kerr et al., 1993; Henriksén et al., 1995), it is difficult to understand why they are reduced in the testes of oestradiol-treated animals in the absence of gonadotrophin replacement. Decreases in germ-cell deaths have not been described previously in hormone-suppressed animals and, therefore, it is likely that they depend on oestrogen effects. Also striking was the statistically significant augmentation of cell death of preleptotene and leptotene spermatocytes after oestradiol plus hMG administration, which was even greater than the increases found in testes from animals treated with oestradiol alone. These increases in cell degenerations may be because the complexity of producing germ-cells in a precise pattern along the seminiferous epithelium cycle requires a coordinative regulatory mechanism that can be impaired by disturbances of endocrine balance caused by hormone treatments. This may be the case particularly during maturing steps, such as the production of preleptotene and leptotene spermatocyes, during which meiosis begins and the passing of spermatocytes through the testicular barrier occurs; therefore, it is logical that hormone concentrations should be more critical at these stages. An alternative explanation for these cell deaths is the possible reduction in androgen receptor binding caused by exogenous oestradiol (Oko and Hrudka, 1984; Gooren, 1989), especially in the case of preleptotene and leptotene spermatocytes (stages VII-XI), but this does not seem to be consistent with the fact that all the experimental animals received equal doses of oestradiol and that these cell deaths in gonadotrophin-supplemented animals were on average 14 times higher than in testosterone-supplemented animals and seven times higher than in rats treated with oestradiol alone.

In our analysis of viable cell populations, the number of cell counts per Sertoli cell nuclei in hormone-supplemented animals 
revealed that almost all of the cell types were significantly increased with respect to those in control animals. In addition, cell counts per tubular cross-section (corrected to Abercrombie's formula) were almost restored to normal in testosterone- as well as in gonadotrophin-supplemented animals. However, no significant increases in the number of living cells were found at nearly all the maturing steps. The increase in the number of preleptotene and zygotene spermatocytes remained significant in rats treated with oestradiol alone and in animals from the gonadotrophinsupplemented group, which contrasts with the fact that the number of dying cells also increased.

FSH has been shown to stimulate mouse (Haneji et al., 1984) and immature rat (Boitani $e t$ al., 1993) spermatogonia in vitro and to increase DNA synthesis in type B spermatogonia and preleptotene spermatocytes from the adult rat (Henriksén et al., 1996). Therefore, an increase in the number of germ cells after gonadotrophin replacement is consistent with these previous findings but is in direct contrast to the fact that an increase in the number of $\mathrm{B}$ spermatogonia and preleptotene spermatocytes per tubular cross-section occurs in response to oestradiol treatment alone, when $\mathrm{FSH}$ and $\mathrm{LH}$ are significantly diminished. $A$ decrease in the number of $B$ spermatogonia has been reported after hypophysectomy (Orth and Christensen, 1978; Clermont and Morgentaler, 1955). It is now known that cell death is subject to the same kinds of social controls that operate on cell proliferation (Harrington et al., 1994). There appears to be a feedback mechanism operating between cell proliferation and cell death, such that when one increases the other increases concomitantly to maintain a homeostasis in total tissue mass (Raff, 1992; Amati et al., 1994). Likewise, although further studies are required, it is possible that oestradiol is involved, by a direct or indirect mechanism, in paracrine controls leading to the modulation of germ-cell apoptosis.

In conclusion, although the nature of testicular architecture and the multiple interactions occurring at a cellular level make the design of studies and interpretation of data generated difficult, this study provides quantitative data concerning the number of dying and living germ-cells occupying the seminiferous epithelium of the adult rat after oestradiol treatment and after testosterone and gonadotrophin replacement. These data strongly suggest that oestradiol plays a role in the paracrine control of spermatogenesis in the adult rat testis.

The authors thank L. Santiago and M. Lázaro for excellent technical assistance.

\section{References}

Abercrombie M (1946) Estimation of nuclear population from microtome sections Anatomical Record 94 239-247

Amati B, Littlewood T, Evan G and Land H (1994) The c-Myc protein induces cell cycle progression and apoptosis through dimerisation with Max $E M B O$ Journal 12 5083-5087

Awoniyi CA, Santulli R, Chandrashekar V, Schanbacher BD and Zirkin BR (1989) Quantitative restoration of advanced spermatogenic cells in adult male rats made azoospermic by active immunization against luteinizing hormone or gonadotrophin-releasing hormone Endocrinology 125 1303-1309

Billig H, Furuta I, Rivier C, Tapanainen J, Parvinen M and Hsueh JW (1995) Apoptosis in testis germ-cells: developmental changes in gonadotrophin dependence and localization to selective tubule stages Endocrinology 136 5-12

Blanco-Rodriguez J and Martinez-Garcia C (1996a) Spontaneous germ-cell death in the testis of the adult rat takes the form of apoptosis: assessment of cell types that exhibit the capability to undergo apoptosis during spermatogenesis Cell Proliferation 29 13-31

Blanco-Rodriguez J and Martínez-García C (1996b) Induction of apoptotic cell death in the seminiferous tubule of the adult rat testis: assessment of the germ-cell types that exhibit the ability to enter apoptosis after hormone treatment International Journal of Andrology 19 237-247

Blanco-Rodriguez J and Martinez-Garcia C (1996c) Further observations on the early events that contribute to establishing the morphological pattern shown by the hormone suppressed testis Tissue and Cell 28 387-399

Boitani C, Politi MG and Menna T (1993) Spermatogonial cell proliferation in organ culture of immature rat testis Biology of Reproduction 48 761-767

Brinkworth MH, Weinbauer GF, Schlatt S and Nieschlag E (1995) Identification of male germ-cells undergoing apoptosis in adult rats Journal of Reproduction and Fertility 105 25-33

Clermont $Y$ and Morgentaler H (1955) Quantitative study of spermatogenesis in the hypophysectomized rat Endocrinology 57 369-382

Dym M and Madhwa Raj HG (1977) Response of adult rat Sertoli cells and Leydig cells to depletion of luteinizing hormone and testosterone Biology of Reproduction 17 676-696

Ghosh S, Sinha-Hikim AP and Russell LD (1991) Further observations of stage-specific effects seen after short-term hypophysectomy in the rat Tissue and Cell 23 613-630

Gooren, L (1989) Androgens and estrogens in their negative feedback action in the hypothalamo-pituitary-testis axis: site of action and evidence of their interaction Journal of Steroid Biochemistry 33 757-761

Haneji T, Maekawa M and Nishimune Y (1984) Vitamin A and folliclestimulating hormone synergistically induce differentiation of type A spermatogonia in adult mouse cryptorchid testes in vitro. Endocrinology 114 801-805

Harrington EA, Fanidi A and Evan GI (1994) Oncogenes and cell death Current Opinion in Genetics and Development 4 120-129

Heikinheimo O, Mahong MC, Gordon K, Hsiu JG, Hodgen GD and Gibbons WE (1995) Estrogen and progesterone receptor mRNA are expressed in distinct patterns in male primate reproductive organs Journal of Assisted Reproduction and Genetics 12 198-204

Henriksén E, Hakovirta H and Parvinen M (1995) Testosterone inhibits and induces apoptosis in rat seminiferous tubules in a stage-specific manner: in situ quantification in squash preparations after administration of ethane dimethane sulfonate Endocrinology 136 3285-3291

Henriksén K, Kangasniemi M, Parvinen M, Kaipia A and Hakovirta H (1996) In vitro, follicle-stimulating hormone prevents apoptosis and stimulates deoxyribonucleic acid synthesis in the rat seminiferous epithelium in a stage-specific fashion Endocrinology 137 2141-2149

Hess RA (1990) Quantitative and qualitative characteristics of the stages and transitions in the cycle of the rat seminiferous epithelium: light microscopic observations of perfusion-fixed and plastic-embedded testes Biology of Reproduction 43 525-542

Huckins C (1978) The morphology and kinetics of spermatogonial degeneration in normal adult rat: an analysis using a simplified classification of the germinal epithelium Anatomical Record 190 905-926

Jong FH, Uilenbroek J and Van der Molen HJ (1975) Oestradiol-17 $\beta$, testosterone and gonadotrophins in oestradiol-17 $\beta$ treated intact adult male rats Journal of Endocrinology 65 281-282

Kerr JB, Millar M, Maddocks S and Sharpe RM (1993) Stage-dependent changes in spermatogenesis and Sertoli cells in relation to the onset of spermatogenic failure following withdrawal of testosterone Anatomical Record 235 547-559

Le Magueresse B and Jegou B (1988) Paracrine control of immature Sertoli cells by adult germ-cells in the rat (an in vitro study). Cell-cell interactions within the testis Molecular and Cellular Endocrinology 58 65-72

Lubahn DB, Moyer JS, Golding TS, Couse JF, Korach KS and Smithies O (1993) Alteration of reproductive function but not prenatal sexual development after insertional disruption of the mouse estrogen receptor gene Proceedings of the National Academy of Science USA 9011 162-11 166

McLachlan RI, Wreford NG, Meachem SJ, De Kretser DM and Robertson M (1994a) Effects of testoterone on spermatogenic cell populations in the adult rat Biology of Reproduction 3 705-709

McLachlan RI, Wreford NG, Tsonis C, Kretser DM and Robertson DM (1994b) Testosterone effects on spermatogenesis in the gonadotrophin-releasing hormone-immunized rat Biology of Reproduction 50 271-280 
Marathe GK, Shetty J and Dighe RR (1995) Selective immunoneutralization of luteinizing hormone results in the apoptotic cell death of pachytene spermatocytes and spermatids in the rat testis Endocrine 3 705-709

Nakhla AM, Mather JP, Janne OA and Bardin CW (1984) Estrogen and androgen receptors in Sertoli, Leydig, mioid and epithelial cells: effect of time in culture and cell density Endocrinology 115 121-128

O'Donnell L, McLachlan Rl, Wredford NG and Robertson DM (1994) Testosterone promotes the conversion of round spermatids between stages VII and VIII of the rat spermatogenic cycle Endocrinology 135 2608-2614

Oko R and Hrudka F (1984) Comparison of the effects of gossypol, estradiol-17 beta and testosterone compensation on male rat reproductive organs Biology of Reproduction 30 1198-1207

Orth J and Christensen AK (1978) EM autoradiographic localization of specifically bound 125[-FSH on spermatogonia in rat testes Anatomical Record 190 497-502

Raff $M$ (1992) Social controls on cell survival and cell death Nature 356 $397-400$

Russell LD and Clermont Y (1977) Degeneration of germ-cells in normal, hypophysectomized and hormone treated hypophysectomized rats Anatomical Record 187 347-360

Russell LD, Malone JP and Karpas SL. (1981) Morphological pattern elicited by agents affecting spermatogenesis by disruption of its hormonal stimulation Tissue and Cell 13 369-380

Sharpe RM, Donachie K and Cooper I (1987) Re-evaluation of the intratesticular level of testosterone required for quantitative maintenance of spermatogenesis in the rat journal of Endocrinology 117 19-26
Sharpe RM, Fraser HM and Ratnasooriya WD (1988) Assessment of the role of Leydig cell products other than testosterone in spermatogenesis and fertility in adult rats International Journal of Andrology 11 507-523

Sharpe RM, Maddocks S and Kerr JB (1990) Cell-cell interactions in the control of spermatogenesis as studied using Leydig cell destruction and testosterone replacement American Journal of Anatomy 188 3-20

Shetty J, Marathe GK and Dighe RR (1996) Specific immunoneutralization of FSH leads to apoptotic cell death of the pachytene spermatocytes and spermatogonial ceils in the rat Endocrinology 137 2179-2182

Sinha Hikim AP, Wang C, Leung A and Swerdloff RS (1995) Involvement of apoptosis in the induction of germ-cell degeneration in adult rats after gonadotrophin-releasing hormone antagonist treatment Endocrinology 136 $2770-2775$

Smith EP, Boyd JB, Frank GR, Takahashii H, Cohen RM, Specker B, Williams TC, Lubahn DB and Korach SK (1994) Estrogen resistance caused by a mutation in the estrogen-receptor gene in a man New England Journal of Medicine 331 1056-1061

Steinberger E (1971) Hormonal control of mammalian spermatogenesis Physiological Reviews 51 1-22

Tapanainen JS, Tilly JL, Vihko KK and Hsueh AJW (1993) Hormonal control of apoptotic cell death in the testis: gonadotrophins and androgens as testicular cell survival factors Molecular Endocrinology 7 643-650

Van der Molen HJ, Brinkmann AO, Jong FH and Rommerts FF (1981) Testicular oestrogens Journal of Endocrinology 89 33-45 